\title{
PLS MODELLING OF FACTORS AFFECTING THE COOPERATION BETWEEN SALES AND MARKETING IN PHARMACEUTICAL AND NON-PHARMACEUTICAL MANUFACTURING FIRMS
}

\section{MODELIRANJE ČIMBENIKA KOJ UTJEČU NA SURADNJU IZMEĐU PRODAJE I MARKETINGA U FARMACEUTSKIM I NEFARMACEUTSKIM PROIZVODNIM PODUZEĆIMA PRIMJENOM PLS METODE PARCIJALNIH NAJMANJIH KVADRATA}

\author{
Market-Tržište \\ Vol. 31, No. 2, 2019, pp. 227-247 \\ UDK 658.8:661 \\ DOl http://dx.doi.org/10.22598/mt/2019.31.2.227 \\ Preliminary communication
}

\section{Gabor Hetenyi ${ }^{a}$, Magdolna Szilasi ${ }^{b}$, Attila Lengyel ${ }^{c}$}

a University of Debrecen, Károly Ihrig Doctoral School of Management and Business, Böszörményi street 138, 4032 Debrecen, HUNGARY, e-mail: gaborhetenyi@yahoo.com

b University of Debrecen, Doctoral School of Health Sciences, Nagyerdei street 98, 4032 Debrecen, HUNGARY, e-mail: drmagdolnaszilasi@gmail.com

c University of Debrecen, Department of Tourism, Böszörményi street 138, 4032 Debrecen, HUNGARY, e-mail: guszfraba@ gmail.com

\section{Abstract}

Purpose - This paper aims to explore the manner in which cooperation between sales and marketing in pharmaceutical manufacturing companies (PMC) $(n=16)$ and non-pharmaceutical manufacturing companies (NPMC) $(n=31)$ is affected by selected indicators. It also attempts to demonstrate how the Partial Least Square (PLS) path modelling technique can reveal latent mechanisms in the interplay of the examined factors affecting SM cooperation.

Design/methodology/approach - Data collection was carried out in the form of an online questionnaire. The rating scale data gathered was analyzed using PLS path modelling.

\section{Sažetak}

Svrha - Cilj je rada istražiti kako odabrani indikatori utječu na suradnju između prodaje i marketinga $u$ farmaceutskim $(n=16)$ i nefarmaceutskim proizvodnim poduzećima ( $n=31)$. Isto tako, rad pokušava pokazati kako PLS metoda parcijalnih najmanjih kvadrata, kao tehnika modeliranja staza, može otkriti latentne mehanizme u međusobnom djelovanju istraživanih faktora koji utječu na suradnju između prodaje i marketinga.

Metodološki pristup - Podaci su prikupljeni korištenjem online anketnog upitnika s mjernim ljestvicama. Analizirani su primjenom PLS metode parcijalnih najmanjih kvadrata. 
Findings - Management culture (information exchange, coordination, vision, and communication) as the superblock of the model accounts for a high variance in SM cooperation in both PMCs $\left(R^{2}=0.619\right)$ and NPMCs $\left(R^{2}=0.741\right)$. Out of the three variables determining management culture, in PMCs it is coordination $\left(R^{2} \%=44\right)$, while in NPMCs it is information exchange $\left(R^{2} \%=57\right)$ that accounts for most of the variance. The results clearly demonstrate that there are factors affecting SM cooperation that work differently in PMCs and NPMCs.

Limitations - As the analysis in this research study was based on a convenience sample, its result should be interpreted with caution and cannot be generalized.

Originality/value - This is the first time that the SM interface mechanisms were compared in PMCs and NPMCs using PLS path modelling. PLS revealed latent relationships and mechanisms that play an important role in optimising SM cooperation.

Keywords - factor of success, sales, marketing, cooperation, coordination, pharmaceutical industry
Rezultati i implikacije - Menadžerska kultura (razmjena informacija, koordinacija, vizija i komunikacija) kao superblok $u$ modelu objašnjava veliki udio varijance $u$ suradnji između prodaje i marketinga i u farmaceutskim $\left(R^{2}=0,619\right)$ i u nefarmaceutskim proizvodnim poduzećima $\left(R^{2}=0,741\right)$. Od tri varijable koje određuju menadžersku kulturu, najveću varijancu imaju koordinacija $\left(\mathrm{R}^{2} \%=\right.$ 44) u farmaceutskim, a razmjena informacija $\left(R^{2} \%=57\right)$ u nefarmaceutskim prozvodnim poduzećima. Rezultati jasno pokazuju da postoje čimbenici koji utječu na suradnju između prodaje i marketinga, a djeluju različito u farmaceutskim i nefarmaceutskim proizvodnim poduzećima.

Ograničenja - Analiza se temelji na prigodnom uzorku, stoga se rezultati trebaju interpretirati s oprezom i ne mogu se generalizirati.

Doprinos - Ovo je prvi put da se uspoređuje međusobno djelovanje prodaje i marketinga u farmaceutskim i nefarmaceutskim proizvodnim poduzećima korištenjem metode PLS modeliranja staza. PLS je otkrio latentne odnose i mehanizme koji imaju važnu ulogu u optimiziranju suradnje između prodaje i marketinga.

Ključne riječi - čimbenici uspjeha, prodaja, marketing, suradnja, koordinacija, farmaceutska industrija 


\section{INTRODUCTION}

The present research study has two goals. On the one hand, it aims to explore the manner in which cooperation between sales and marketing (SM) in pharmaceutical manufacturing companies (PMC) and non-pharmaceutical manufacturing companies (NPMC) is affected by eleven preselected factors. The other aim of this research study is to demonstrate how Partial Least Square (PLS) path modelling technique can reveal latent mechanisms in the interplay of the examined factors that affect SM cooperation in the two types of companies.

In addition to the fact that this is a virtually unresearched area, there are several reasons why the authors decided to examine possible differences between PMCs and NPMCs specifically. The pharmaceutical industry has been growing at an astounding rate globally in recent years (Buncher \& Tsay, 2019). In Hungary, similarly to the USA or Japan, more than $2 \%$ of the GDP is pharmaceutical spending (Organisation for Economic Co-operation and Development, 2017); over $30 \%$ of all healthcare spending is pharmaceutical spending (Inotai, Csanádi, Harsányi \& Németh, 2017). For a country such as Hungary, the development of knowledge-intensive industries relying heavily on research and development can be a sound long-term economic strategy (Antalóczy \& Sass, 2018).

The pharmaceutical sector needs to be viewed in the context of strict EU regulations and legal frameworks with regard to patents, marketing authorization, pricing, and other market surveillance activities (Schweitzer \& Lu, 2018; Garattini $\&$ Padula, 2018). The complex and strict security regulations and the long authorization and special patenting procedures (Kumazawa, 2017) set PMCs apart from other NPMCs in many ways. A detailed descussion of these differences would go beyond the scope of this paper; however, the authors attempt to uncover possible differences between PMCs and NPMCs in optimising the cooperation of SM departments. As PMCs differ from NPMCs in many respects, it was hy- pothesized that there might be differences in how employees of SM departments evaluate factors that the SM optimization literature has found to significantly affect the overall efficiency of the companies.

The pharmaceutical industry is one of the most complex sectors with the key corporate task of conquering new markets, which is a major challenge for the SM departments responsible (Katsanis, 2015). The SM role in winning new markets and patents has been strengthening in PMC firms (Nagy, 2018). When it comes to meeting market and customer needs, the two most important departments are precisely sales and marketing (Bauer, 2000; Bruhn \& Homburg, 2004; Pepels, 2012; Keszey \& Biemans, 2016). It is evident that the successful management of any organization requires future-orientated strategic alignment of these departments (Homburg, Vomberg, Enke \& Grimm, 2015). The past decades have seen a large amount of research on the productive cooperation between sales and marketing, leading to the conclusion that a harmonious cooperation between these areas has a marked positive effect on the organization's performance (Kotler, Rackham \& Krishnaswamy, 2006; Guenzi \& Troilo, 2006; Guenzi \& Troilo, 2007; Biemans, Brenčič \& Malsche, 2010; Ernst, Hoyer \& Rübsaamen, 2010; Snyder, McKelvey \& Sutton, 2016). Sales and marketing departments are mutually dependent on one another, since one's performance is greatly affected by the performance of the other (Dewsnap \& Jobber, 2000; Le Meunier-FitzHugh \& Piercy, 2007b; Le Meunier-FitzHugh \& Le Meunier-FitzHugh, 2016).

Out of all the processes contributing to profitability in PMCs, a smooth cooperation between these two departments is crucial (Krush, Malshe, Al-Khatib, Al-Jomaih \& Katoua, 2015). Thus, the management needs to build trust and efficient cooperation between these departments, relying on information and know-how from sales, and incorporate it into strategic marketing decisions in order to promote product development and competitiveness. 
PLS path modelling is a second generation structural equation modelling (SEM) approach that can be efficiently used if normality of the data cannot be assumed and the sample size is relatively small, and the measurement level of the data is ordinal (Tenenhaus, Vinzi, Chatelin \& Lauro, 2005; Wong, 2013; Henseler, 2018). PLS is widely used in marketing research (Hair, Ringle \& Sarstedt, 2011). As Hair et al. point out, "Researchers especially appreciate SEM's ability to assess latent variables at the observation level (outer or measurement model) and test relationships between latent variables on the theoretical level (inner or structural model)." (Hair et al., 2011, p. 414).

The choice of variables in the measuring instrument and subsequently in the constructs (blocks) was made based on what earlier SM literature considers key factors in determining the success of SM cooperation. Owing to the lack of an available and adequate measuring instruments in the SM literature, a compact but adequate rating was developed to serve scale as a measuring instrument.

Peer-reviewed literature on how the optimization of the SM interface differs in PMCs and NPMCs is virtually non-existent. Even recently published books (Lidstone \& MacLennan, 2017; Holden, 2018) on pharmaceutical marketing do not analyze the importance of SM interface optimization. Also, while there is an abundance of literature on the utilization of PLS path modelling in the sales or marketing context in general (O'Cass, Ngo \& Siahtiri, 2015; Swaim, Maloni, Bower \& Mello, 2016; Abu Farha \& Elbanna, 2018) and for PMC in general (Azizi, Ghytasivand \& Fakharmanesh, 2012; Kohan, Rafie \& Hosseini, 2014), the application of this SEM technique for SM optimization of PMCs is not available either. Literature on the factors selected for scrutiny and previous context-relevant application of the PLS path modelling as well as literature addressing why SM management in PMC and NPMC might be different will be reflected upon in the literature review section.

\section{LITERATURE REVIEW AND THEORETICAL FRAMEWORK}

A close and clear relationship between SM departments, especially between their leaders, is extremely important in the strategic development of the firm (Strahle, Spiro \& Acito, 1996; Ahsan, 2018). Since both sales and marketing have turnover-related tasks, there are bound to be interactions and interdependencies between them. It is these dependencies that make the cooperation of the two departments so interesting and rather unstable (Haase, 2006; Dewsnap \& Jobber, 2002; Johnson, Matthes \& Friend, in press). As research evidence demonstrates, the relationship of SM departments is not smoothly integrated in most companies (Beverland, Steel \& Dapiran, 2006; Homburg \& Jensen, 2007; Madhani, 2015).

There are a number of interface issues between sales and marketing (Kotler et al., 2006; Malshe, Friend, Al-Khatib, Al-Habib \& Al-Torkistani, 2017b), which, if not resolved, will put the organization at risk of making the work of both departments counterproductive and inefficient, thus negatively affecting the performance of the organization (Haase, 2006; Moncrief, 2017). The arising conflicts can be organizational (conflicting targets, incentives), personal (mindset, behavioral patterns), or informational (communication issues) (Cespedes, 1993; Cespedes, 1994; Specht, 1995; Specht, 2000; Egelhoff \& Wolf, 2017; Rahim, 2017). Proper management of conflicts has a significant effect on the efficiency of pharmaceutical firms (Al-jawazneh, 2015). Conflicts are often a result of different perspectives of these departments. Sales departments tend to set monthly or quarterly targets, whereas marketing usually has more long-term visions with no short-term sales commitments (Krafft, 1995; Rouziès et al., 2005; Malshe, Johnson \& Viio, 2017a). It is interesting to note that, according to literature, not all conflicts "are created equal" and that conflicts, especially functional conflicts between the two departments, can even be 
beneficial (Matsuo, 2006; Guenzi \& Troilo, 2007; Massey \& Dawes, 2007).

Potential information-related conflicts can be linked to communication and information exchange between departments (Quirke, 2017; Thornton, 2019) on the one hand, and the necessary technical background, hardware and software requirements on the other (Wierum, 2001; Wang, Fang, Qureshi \& Janssen, 2015). Malshe and others (2017a) found empirical evidence that SM communication paucity can seriously undermine trust between the two departments; this, in turn, can have a strong negative effect on the soverall company performance.

Communication deficiencies can lead to a situation where marketing measures are implemented without taking sales aspects into consideration, or where sales staff gets to know about company promotions and activities from their customers (Martinez \& Hurtado, 2018). Exchanging information is key to strategic planning, especially in the early stages where identifying potential opportunities and risks is crucial (Omar, Ramayah, Lo, Sang \& Siron, 2010; Bigdeli, Kamal \& de Cesare, 2012; Huang, Wu, Wen, Hsin-Fei \& Hairui, 2017). Further communication deficiencies can be caused by an incompatible/missing technical network between the departments (Järvinen \& Taiminen, 2016). Erturk and He (2018) analyzed how a highly integrated customer relationship management (CRM) system can influence the mutually dependent SM operations. Dalla Pozza, Goetz and Sahut (2018) pointed out that linking sales analysis with marketing segmentation through a well-functioning common CRM system can greatly help competitiveness. Having assessed two years of experience with an online CRM platform, Pohludka and Štverková (2019) concluded that it has proved to be a robust system for both sales and marketing.

Proper alignment and coordination of sales and marketing is instrumental in ensuring a cost-efficient cooperation of the two departments (Kotler et al., 2006; Mayer \& Nyhuis, 2016). As Morgan and Slotegraaf (2012, p. 102) point out in connec- tion with B2B firms marketing capabilities, "...the development of different capabilities requires the coordination of various resources, skills and routines." The necessity of this form of coordination is also inevitable when it comes to harmonizing the relationship and interface interactions of SM departments within the company.

A strong and clearly communicated strategic corporate vision is another key element of success (Tomek, Vávrová, Červenka, Naščáková \& Tomčíková, 2016; Balmer, 2017). In an early empirical study, Baum, Locke and Kirkpatrick (1998) found that a clear company vision had a positive effect on the overall company performance only if it was clearly communicated to the employees. The importance of effective internal communication was also affirmed later by Ferdous (2008) and Martinez and Hurtado (2018).

According to Jo Hatch and Schultz (2003, p. 1047), strategic corporate vision is: "The central idea behind the company that embodies and expresses top management's aspiration for what the company will achieve in the future." A shared vision of SM departments can greatly enhance the effectiveness of cooperation between them (Madhani, 2016). With regard to pharmaceutical companies, analysing the example of GlaxoSmithKline, Birkinshaw, Zimmermann and Raisch (2016) highlight the importance that a strong strategic vision plays in the adaptation capabilities of PMCs.

Lamasheva (2004) believes that defining common targets and objectives is an inevitable element of coordination and must be a part of every company's life in order to maintain competitiveness and ensure cooperation (Raab, 2010). The existence and appropriate communication of corporate culture - as a set of management measures - will promote teamwork and reduce conflict (Morgan \& Piercy, 1998; Song, Xie \& Dryer, 2000).

One way to deal with communication defficiencies and improve the quality of cooperation between sales and marketing is the introduction of regular meetings and common training programs for the employees of the two depart-

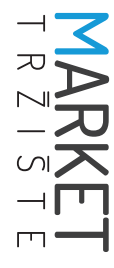




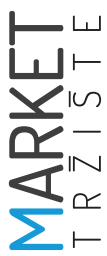

ments. The importance of cross-functional SM training was established by Kahn (1996) and later confirmed by Le Meunier-FitzHugh and Piercy (2007a). Matthyssens and Johnston pointed to the fact that "Joint training and development programs also stimulate the interface. A common jargon and thinking pattern is provided and the residential atmosphere of seminars leads to open discussions under professional guidance." (Matthyssens \& Johnston, 2006, p. 344). Kotler and others (2006) developed a rating scale measuring instrument to tap into the SM relationship. One item to be rated on their scale was "Sales and Marketing jointly develop and deploy training programs, events, and learning opportunities for their respective staffs." (Kotler et al., 2006, p. 6). In their study, they also underlined the importance of organizing regular common meetings for SM employees.

Literature has confirmed that sharing common goals can improve cooperation between the two departments (Kahn, 1996; Le Meunier-FitzHugh \& Lane, 2013). Assessing the determining factors of SM integration, Sleep, Lam, and Hulland conclude: "Creating common goals or encouraging joint visits to customers can reduce boundaries. In addition, managers can imple-ment cross-functional teams to increase information and resources sharing across functions to further increase interdependence, which reduces the integration gap and ultimately improves business results." (Sleep, Lam \& Hulland, 2018, p. 15).

When attempting to explain the division of tasks and responsibilities between sales and marketing, it is useful to build on the well-established distinction between the two functions within company operations, as discussed by certain scholars (Homburg, Jensen \& Krohmer, 2008; Homburg, Alavi, Rajab \& Wieseke, 2017). Homburg et al. further clarify that "Sales people are typically responsible for a set of customers in a sales territory or in a specific industry segment, while marketing managers are typically responsible for a specific product or brand offered by the firm" (Homburg et al., 2017, p. 16). Meanwhile, other researchers have attempted to shed some light on the problems arising between these functions as follows: "...lack of collaboration may be caused by lack of understanding of each other's roles, role ambiguity, poor communication, a culture of blame, different perspectives and poor alignment of activities and goals" (Le Meunier-FitzHugh \& Piercy, 2007b, p. 942).

The question of the "ideal customer" in the literature encompasses the various means of profiling the best target group for a certain product or line of products, that is, identifying the customers who are most likely to buy them. Customer profiling has rich literature for both PMCs (Xu \& Walton, 2005; Guido, Pichierri, Pino \& Conoci, 2018; Paglialonga, Patel, Pinto, Mugambi \& Keshavjee, 2019) and NPMCs (Boe, Hamrik \& Aarant, 2001; Walters \& Bekker, 2017; Ghuman \& Mann, 2018). Anshari, Almunawar, Lim, and Al-Mudimigh summarize the importance of profiling by suggesting that "... customer profiling for each and every customer becomes important for business to make sure that the whole CRM' life cycle (sales, marketing, and customer service) are offering personalized and customized services so that each customer will experience differently according to their needs and interest." (Anshari, Almunawar, Lim \& Al-Mudimigh, 2018, p. 6).

While the literature is relatively rich on profiling „ideal” customers of NPMCs and PMCs, previous research on how a shared perception of the ideal customer by SM departments affects their quality of cooperation is non-existent at the moment.

\section{METHODOLOGY}

\subsection{Sample, measuring instrument and research questions}

Our research population was made up of sales, marketing, and management staff of 16 PMCs and 31 NPMCs. Out of the 16 PMCs, 7 were big companies (number of employees $\geq 250$ ) and 9 medium-sized companies (50 $\leq$ number of employees $\leq 250$ ). Out of the 31 NPMCs, 14 were big companies (number of employees $\geq 250$ ) and 17 medium-sized companies (50 $\leq$ number 
of employees $\leq 250$ ). A total of 427 out of the 1033 questionnaires distributed were returned (PMC=147; NPMC=280), giving a response rate of $41 \%$. Six questionnaires contained so many missing data that they were excluded from the statistical analysis, which was carried out using 421 completed questionnaires. Table 1 shows the distribution of respondents by department and company type.

TABLE 1: Percentage distribution of respondents by department and company type

\begin{tabular}{|l|c|c|c|}
\hline Type of company & Marketing & Sales & Management \\
\hline Pharmaceutical & $42 \%$ & $44 \%$ & $14 \%$ \\
\hline $\begin{array}{l}\text { Non- } \\
\text { pharmaceutical }\end{array}$ & $17 \%$ & $57 \%$ & $26 \%$ \\
\hline Entire sample & $28 \%$ & $51 \%$ & $21 \%$ \\
\hline
\end{tabular}

Source: Authors' own calculations

Table 2 contains the 11 statements that respondents had to rate on a 5 -point Likert scale (1=totally disagree, 5=totally agree). The answers to these statements provided the basis for the PLS modelling. In the questionnaire respondents were also asked what areas they would like to change the most in order to improve cooperation. The complete questionnaire can be found as an appendix to this paper.
Questions were grouped in the following blocks: information exchange (V4, V7, V8), coordination (V5, V6, V7, V9), vision (V1, V2), communication (V3), conflicts (V11), and a shared perception of the ideal customer (V10).

In developing our measuring instrument, two main considerations were given the biggest importance. Firstly, an instrumen with an adequate number of variables to serve as a basis for PLS path modelling (Hair et al., 2011) but that is short enough to ensure the highest possible response rate needed to be employed. Secondly, the eleven variables were chosen as we considered them, based on our findings after consulting the literature, to be the key factors in determining the SM cooperation. The earlier literature on SM cooperation and integration used two rating scales: one, developed by Hult, Ketchen and Slater (2002), is a three-item scale focusing on a shared SM vision, and the other a twenty-item scale suggested by Kotler and others (2006). While incorporating some of the ideas (e.g. shared vision, common training programs) provided by them, we considered these two scales inadequate to measure the five blocks of questions detailed earlier.

Our research attempted to find answers to the following research questions:

\section{TABLE 2: Variables used for PLS path modelling}

\begin{tabular}{|l|l|}
\hline Vision (V1) & The company management has a clear vision for the future. \\
\hline $\begin{array}{l}\text { Communication of the vision } \\
\text { (V2) }\end{array}$ & The management communicates the company vision efficiently. \\
\hline SM communication (V3) & The communication between sales and marketing in general is very good. \\
\hline Information exchange (V4) & The SM department information exchange is optimal. \\
\hline Common IT, CRM (V5) & The inter-divisional IT platform (CRM system) greatly helps information exchange. \\
\hline Common training sessions (V6) & SM staff members have regular common training sessions. \\
\hline Common goals for SM (V7) & SM departments share a common goal they both work for. \\
\hline Common meetings for SM (V8) & There are regular common meetings for SM staff. \\
\hline Roles \& responsibilities (V9) & Sales and marketing have clearly defined areas of responsibilities. \\
\hline Ideal customer (V10) & Sales and marketing share a mutual perception of the ideal customer. \\
\hline Conflicts (V11) & Conflicts negatively affect SM cooperation. \\
\hline
\end{tabular}


1. How does information exchange affect SM cooperation in PMCs and NPMCs?

2. How does coordination (common meetings, training sessions, goals, and clearly defined responsibilities) between sales and marketing affect SM cooperation in PMCs and NPMCs?

3. How does the company vision and its communication affect SM cooperation in PMCs and NPMCs?

4. How does management culture (information exchange, coordination, vision) affect SM cooperation in PMCs and NPMCs?

5. How do conflicts between sales and marketing affect SM cooperation in PMCs and NPMCs?

6. How does a shared perception of the ideal customer affect SM cooperation in PMCs and NPMCs?

\subsection{Statistical methods used}

In path modelling /LVPLSM/ (Wold, 1975; Tenenhaus et al., 2005; Rigdon, 2016), questions under the same topic are grouped into blocks, and then the paths and links between these blocks in terms of correlation and regression as well as their strength are examined. Since the model is exploratory, it is suitable for eliminating insignificant links. The path model creates a common latent variable from the observed factors (input variables) in each block (external factor model or measurement model) based on their correlations. Regression links between the latent variables are explored by the internal structural model. The goodness of fit (GoF) indicator was applied to measure the model fit. The AVE indicator is ideally above 0.4-0.5 (Chin, 1998; Fuller, Simmering, Atinc, Atinc \& Babin, 2016). In terms of $R^{2}$ values, $0.02,0.15$, and 0.35 are considered low, medium, and high reference values, respectively (Cohen, 1988). In terms of GOF reference values, $0.10,0.25$, and 0.36 are considered unacceptable, acceptable, and good model fit, respectively (Wetzels, Odekerken-Schröder
\& Van Oppen, 2009). In the interpretation of latent variables, only those items that have a correlation coefficient of above 0.5 can be included in the block. The Fornell and Larcker criterion was applied to measure the discrimination potential of the model (Fornell \& Larcker, 1981; Ab Hamid, Sami \& Sidek, 2017). According to Fornell and Larcker's criterion, the individual latent variables should explain more of the items in their own block than all the other latent variables. Thus, the Fornell and Larcker test shows whether or not the different blocks are sufficiently separated from one another. We used version 0.4.9 of the PLSPM (Partial Least Squares Path Modelling) tools package of the 3.4.4 "Someone-to-lean-on" version of the $R$ statistics software for the estimation of the LVPLS model. The results were subsequently cross-validated by using Smart PLS 3.0 statistical sofware (Wong, 2013), commercial version. The Spearman rank correlation was applied to explore the correlations between factors on the ordinal scale level.

The Chi-square test was applied to the proportions of the areas employees would like to change in each department. In the case of multiple-choice questions, the proportions of respondents marking each individual option and the percentages of each answer option against the total number of answers are presented in the table below.

\section{RESULTS}

Table 3 shows that a high percentage of all respondents marked regular information exchange, common goals, and a common IT platform as the areas within their companies that they would like to change the most. More acceptances were marked the least frequently, compared to the other factors. The three most significant factors show similar tendencies across both company types, and the Chisquare test showed no significant difference between the two groups either $\left(\mathrm{Chi}^{2}=3.65\right.$; $\mathrm{p}<0.601)$. 
TABLE 3: Proportions of areas to change in the sample

\begin{tabular}{|l|c|c|c|}
\hline \multirow{2}{*}{ Factor } & \multicolumn{3}{|c|}{$\%$ of respondents } \\
\cline { 2 - 4 } & $\begin{array}{c}\text { Entire } \\
\text { sample } \\
\text { (N=421) }\end{array}$ & $\begin{array}{c}\text { PMCs } \\
\text { (N=144) }\end{array}$ & $\begin{array}{c}\text { NPMCs } \\
\text { (N=277) }\end{array}$ \\
\hline $\begin{array}{l}\text { Common IT } \\
\text { platform }\end{array}$ & $\mathbf{3 4 . 3}$ & $\mathbf{3 1 . 2}$ & $\mathbf{3 6 . 8}$ \\
\hline $\begin{array}{l}\text { Common } \\
\text { meetings }\end{array}$ & 23.8 & 18.8 & 28.1 \\
\hline Common goals & $\mathbf{3 8 . 1}$ & $\mathbf{3 7 . 5}$ & $\mathbf{3 8 . 6}$ \\
\hline $\begin{array}{l}\text { Regular } \\
\text { information } \\
\text { exchange }\end{array}$ & $\mathbf{4 5 . 7}$ & $\mathbf{3 9 . 6}$ & $\mathbf{5 0 . 9}$ \\
\hline More acceptance & 27.6 & 20.8 & 33.3 \\
\hline Other areas & 13.3 & 8.3 & 17.5 \\
\hline
\end{tabular}

Source: Authors' own calculations

The Chi-square test and cross table analysis were applied to further investigate the differences in response frequencies for the areas of possible change mentioned by the individual departments. In PMCs, distributions can be considered different $\left(\mathrm{Chi}^{2}=21.46 ; \mathrm{p}=0.018\right)$ with a $95 \%$ reliability. Table 4 shows that the largest differences occurred in the case of regular information exchange and common goals. Sales staff require common goals relatively less but would like to see changes in terms of regular information exchange more than the other two groups of respondents. In addition, the management would require a common IT and more acceptance relatively more. NPMCs showed no significant difference in response proportions $\left(C h i^{2}=13.86 ; p=0.179\right)$.

Figure 1 shows a summary of all major blocks of variables, latent variables, and items linked to them as well as their relations to the PMC subsample. The model has two main parts. First, an external factor model that shows how strongly the items in each block are linked to the single latent variable summarising the block. Second, an internal structural model that only signifies relations between the latent variables representing the blocks. Ovals represent the latent variables (blocks), and squares stand for the measured variables. The external measurement model (factor model) contains correlation coefficients, while the internal structural model includes the regression coefficients. All the links (arrows) are significant with a $99 \%$ reliability, with non-significant links depicted by dotted lines. The reliability of the blocks was tested using Dillion Goldstein's RHO index.

TABLE 4: Proportion (\%) of areas to change per field of work and company type

\begin{tabular}{|l|l|c|c|c|c|c|c|}
\hline \multicolumn{2}{|l|}{ Factor } & $\begin{array}{c}\text { Common } \\
\text { IT }\end{array}$ & $\begin{array}{c}\text { Common } \\
\text { meetings }\end{array}$ & $\begin{array}{c}\text { Common } \\
\text { goals }\end{array}$ & $\begin{array}{c}\text { Regular } \\
\text { information } \\
\text { exchange }\end{array}$ & $\begin{array}{c}\text { More } \\
\text { acceptance }\end{array}$ & Other \\
\hline PMC & marketing & 18 & 12 & $\mathbf{3 0}$ & 21 & 12 & 6 \\
\hline & sales & 17 & 14 & 17 & $\mathbf{3 4}$ & 14 & 3 \\
\hline & management & 31 & 8 & $\mathbf{2 3}$ & 15 & 15 & 8 \\
\hline NPMC & marketing & 23 & 18 & 9 & $\mathbf{2 7}$ & 14 & 9 \\
\hline & sales & 17 & 13 & 20 & $\mathbf{2 4}$ & 16 & 10 \\
\hline & management & 16 & 12 & 24 & $\mathbf{2 4}$ & 20 & 4 \\
\hline
\end{tabular}

Source: Authors' own calculations 
FIGURE 1: Estimated LVPLS model and its parameters in PMC

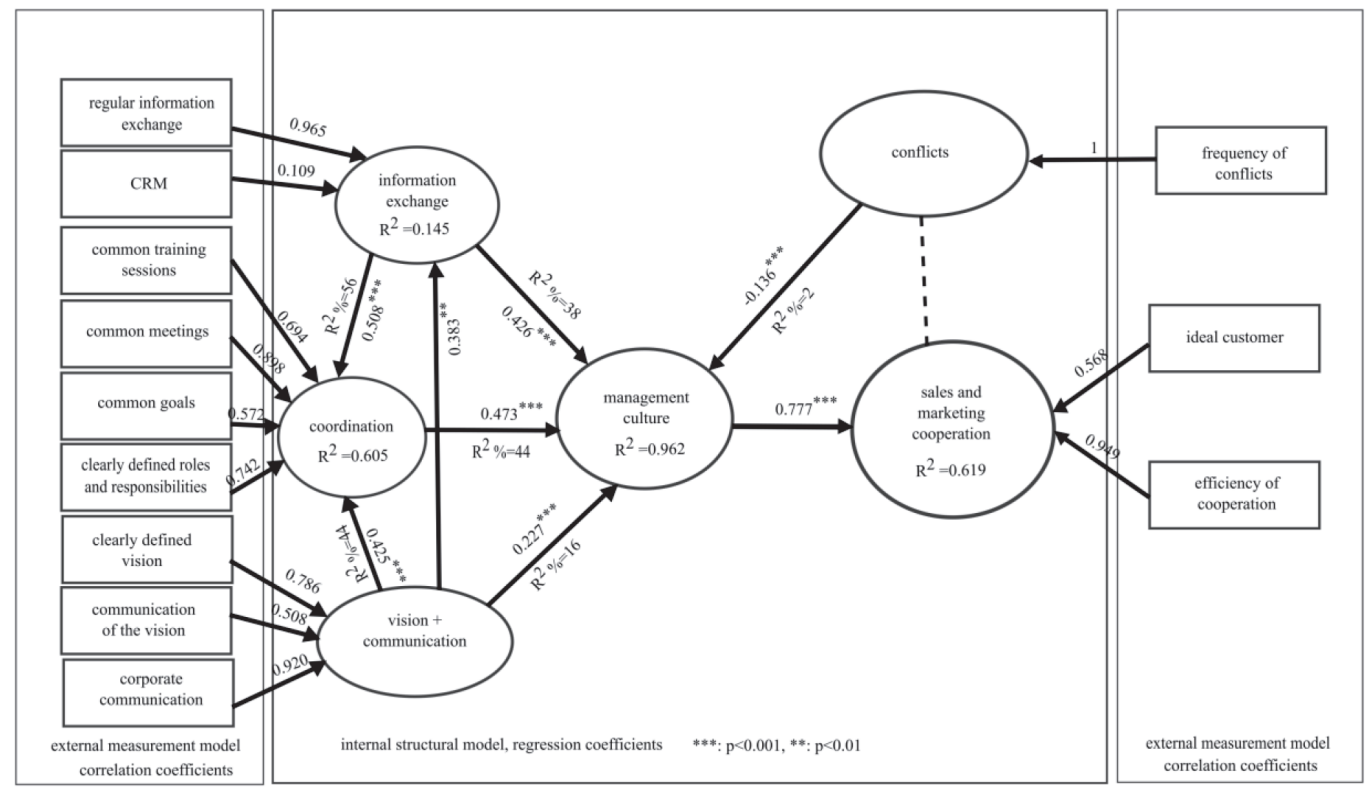

Source: Authors' own calculations

AVE means the average explained variance of the items in the block by the latent variable. $\mathrm{R}^{2}$ means the explained variance proportion in case of the regression of the latent variable.

It is evident that each latent variable explains at least an average $50 \%$ of the deviation of the items linked to it, and the model does not conflict the Fornell and Larcker criterion. The proportion of variance explained in the two models by the coefficient of determination $\left(R^{2}\right)$ is outstanding. The discriminant validity was assessed using the Fornell and Larcker criterion (Ab Hamid et al., 2017). Results for this assessment including AVE indicators is shown in Table 5.
It is evident from Table 6 that all latent variables explain at least $50 \%$ of the variance of the respective items, and the model does not violate the Fornell Larcker criterion. Correlation of conflict was not significant ( $p>0.05)$ with any of the indicators. The two main regressions of the model were the estimation of coordination based on information exchange and vision ( $\left(R^{2}=0.605\right)$, and the estimation of cooperation based on the other latent variables $\left(R^{2}=0.619\right)$. As $R^{2}$ values are high, the explanatory power of the model can be considered to be high too.

The Bootstrap simulation was applied for the validation of the above model, where 500 ran-

TABLE 5: Key statistics of the LVPLS model for PMCs

\begin{tabular}{|l|c|c|c|c|c|c|c|c|}
\hline Latent variable & $\mathbf{R}^{\mathbf{2}}$ & $\mathbf{R H O}$ & $\mathbf{A V E}$ & $\mathbf{1}$ & $\mathbf{2}$ & $\mathbf{3}$ & $\mathbf{4}$ & $\mathbf{5}$ \\
\hline Vision (1) & c.b.c & 0.852 & 0.574 & $\mathbf{0 . 7 5 8}$ & $<0.001$ & 0.010 & 0.192 & 0.006 \\
\hline Coordination (2) & 0.605 & 0.851 & 0.542 & 0.620 & $\mathbf{0 . 7 3 6}$ & $<0.001$ & 0.987 & $<0.000$ \\
\hline Information exchange (3) & 0.145 & 0.732 & 0.472 & 0.383 & 0.671 & $\mathbf{0 . 6 5 0}$ & 0.249 & $<0.000$ \\
\hline Conflicts (4) & c.b.c & c.b.c & n.a. & 0.200 & -0.003 & -0.178 & c.b.c & 0.238 \\
\hline Cooperation (5) & 0.619 & 0.867 & 0.660 & 0.406 & 0.735 & 0.643 & -0.182 & $\mathbf{0 . 8 1 2}$ \\
\hline
\end{tabular}

c.b.c.=cannot be calculated

Source: Authors' own calculations 
dom samples were created by sampling with replacement from the original data. This means that the correlation coefficient of both the internal and the external model was estimated in all 500 samples, and the average and standard error was calculated (Chin, 1998; Samart, Jansakul \& Chongcheawchamnan, 2018). Model parameters where the average is more than double the standard error (SE) are considered statistically significant. Based on this criterion, the regression coefficients of the sample were proven valid. In order to verify that during the discussion of the path coefficients, the standard errors will always be provided as well. With regard to the "management culture" superblock, the GOF of the internal structural model was 0.583 , the GOF value of the external model was 0.521, and the entire model had a GOF of 0.551 , thus showing an excellent fit.

"Cooperation between sales and marketing" was the first result variable in the model that was directly affected by the elements of management culture (information exchange, clear corporate vision, coordination). Model estimates suggest that coordination is the most important factor of corporate culture, with an effect of $44 \%$, followed by information exchange that affects cooperation through management culture at $38 \%$. The regression coefficient of the management culture is 0.777 ( $t=7.95 ; p<0.001, \mathrm{SE}=0.098)$ with regards to cooperation. Within management culture, a significant regression parameter (beta $=0.426$ ) was estimated for information exchange ( $t=9.80 ; p<0.001, S E=0.091)$, coordination (beta=0.473; $t=9.52 ; p<0.001, S E=0.089$ ), and clear corporate vision (beta $=0.227 ; t=5.15$; $\mathrm{p}<0.001$, $\mathrm{SE}=0.110$ ). The regression coefficient of conflicts was $-0.136(t=-4.10 ; p<0.001, S E=0.033)$ with regards to the management culture.

External measurement models also provide important information. Rather strong correlations were found between "coordination" as the most important factor and the items in the block. Coordination is most strongly affected by common meetings ( $r=0.898 ; \mathrm{t}=13.22 ; \mathrm{p}<0.001)$ and clear roles and responsibilities $(r=0.742$; $t=7.17 ; p<0.001)$. Latent variables of "vision" and "communication" are most strongly linked to

FIGURE 2: Estimated LVPLS and its parameters in non-pharmaceutical companies

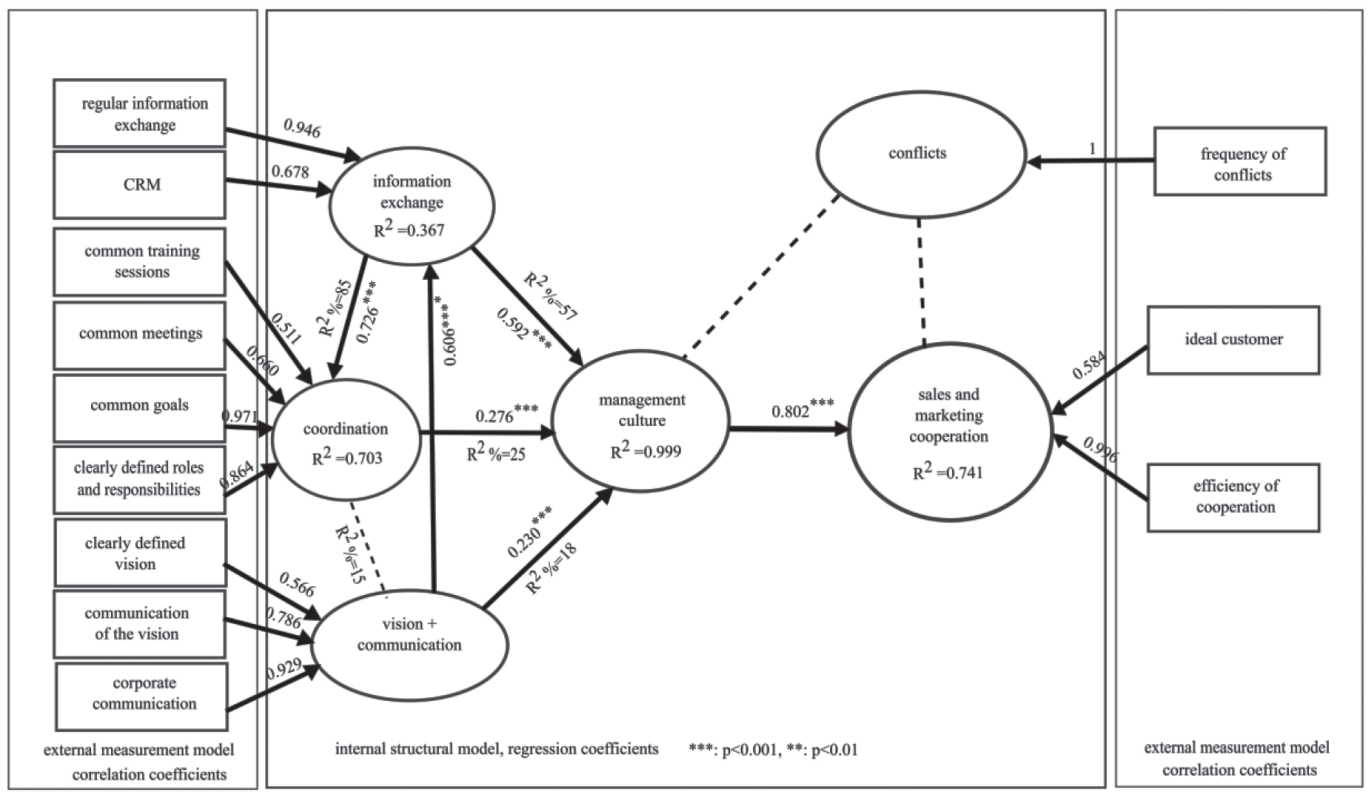

Source: Authors' own calculations 
corporate communication ( $r=0.920 ; \quad t=15.21$; $p<0.001)$ and the definition of the vision itself $(r=0.786 ; t=8.24 ; p<0.001)$. Latent variable of "sales and marketing cooperation" obviously has the strongest correlation to the efficiency of cooperation ( $r=0.949 ; t=19.51 ; p<0.001)$. A rather weak, non-significant correlation was found to exist between CRM and information exchange $(r=0.109 ; t=0.71 ; p=0.481)$.

In comparison, the analysis and the research model were applied to NPMCs as well, with the results shown in Figure 2 below. The Bootstrap simulation was also applied in the validation of the above model, with 500 random samples by sampling with replacement from the original data. The average of the model parameters was more than double the standard error (SE) and can be considered statistically significant. Based on this criterion, the regression coefficients of the sample were provens valid. With regard to the "management culture" superblock, the GOF of the internal structural model was 0.703 , the GOF value of the external model 0.603 and the entire model had a GOF of 0.651, which shows an excellent and better fit compared to the model of PMCs.

The proportion of variance explained in the two models by the coefficient of determination $\left(R^{2}\right)$ is outstanding. Similarly to the model for PMCs, the discriminant validity was assessed using the Fornell and Larcker criterion (Ab Hamid et al., 2017). Results for this assessment including AVE indicators is shown in Table 6. The 'marketing and sales cooperation' factor is directly and sig- nificantly affected by the elements of the management culture (information exchange, clear corporate vision, coordination). However, model estimates revealed a difference as compared to the PMC model, since the key factor affecting cooperation through the management culture was not coordination but information exchange (57\%).

It is evident from Table 6 that all latent variables explain at least $50 \%$ of the variance of the respective items, and the model does not violate the Fornell Larcker criterion. Correlation of conflict and information exchange was significant $(p<0.01)$. The two main regressions of the model were the estimation of coordination based on information exchange and vision $\left(R^{2}=0.703\right)$, and the estimation of cooperation based on the other latent variables $\left(R^{2}=0.741\right)$. As $R^{2}$ values are high, the explanatory power of the model can be considered to be high too. The regression coefficient of the management culture is 0.802 $(t=10.17 ; p<0.001, S E=0.074)$ with regard to cooperation. Within the management culture, a significant regression parameter (beta $=0.592$ ) was estimated for both the information exchange $(t=55.67 ; \mathrm{p}<0.001, \mathrm{SE}=0.137)$ and coordination (beta=0.276; $t=29.27 ; p<0.001, S E=0.119$ ), as well as a clear corporate vision (beta $=0.230 ; t=35.63$; $\mathrm{p}<0.001$, $\mathrm{SE}=0.061$ ). Our results have revealed further differences with regard to clearly communicated and implemented corporate vision (beta=0.168; $t=1.75 ; p=0.087$, SE=0.135). This factor did not contribute to better coordination and integration of the sales and marketing de-

TABLE 6: Key statistics of the LVPLS model for NPMCs

\begin{tabular}{|c|c|c|c|c|c|c|c|c|}
\hline Latent variable & $\mathbf{R}^{2}$ & RHO & AVE & 1 & 2 & 3 & 4 & 5 \\
\hline Vision (1) & c.b.c & 0.861 & 0.600 & 0.775 & $<0.001$ & $<0.001$ & 0.149 & $<0.001$ \\
\hline Coordination (2) & 0.703 & 0.885 & 0.597 & 0.369 & 0.773 & $<0.001$ & 0.041 & $<0.001$ \\
\hline Information exchange (3) & 0.367 & 0.825 & 0.678 & 0.367 & 0.684 & 0.823 & $<0.001$ & $<0.001$ \\
\hline Conflicts (4) & c.b.c & c.b.c & c.b.c & 0.039 & 0.078 & 0.259 & c.b.c & $<0.001$ \\
\hline Cooperation (5) & 0.741 & 0.860 & 0.667 & 0.308 & 0.706 & 0.688 & 0.217 & 0.817 \\
\hline
\end{tabular}

c.b.c=cannot be calculated

Source: Authors' own calculations 
partments since it explained only $15 \%$ of the variance of coordination, with information exchange accounting for $85 \%$. Similarly to PMCs, however, a clearly communicated and implemented corporate vision (beta $=0.606$; $t=5.49$; $\mathrm{p}<0.01, \quad \mathrm{SE}=0.074)$ encourages information exchange between sales and marketing. Still, this impact is much stronger in NPMCs than in PMCs. Further significant differences were seen in the case of conflicts (beta=-0.006; $t=-1.051$; $p=0.298$, $S E=0.076$ ), which showed no significant negative effects.

A comparison of the external measurement models reveals only one significant difference between pharmaceutical and non-pharmaceutical companies. Common goals have the most important impact on coordination in non-pharmaceutical companies, whereas common meetings are the key factor in pharmaceutical companies.

\section{DISCUSSION AND CONCLUSION}

Based on the above results, the answers to our initial research questions are as follows:

1. How does information exchange affect SM cooperation in PMCs and NPMCs?

Information exchange proved to be an important component of the management culture, and hence an important factor affecting SM cooperation in both PMCs ( $\left.\mathrm{R}^{2} \%=38\right)$ and NPMCs $\left(R^{2} \%=57\right)$, the latter being more emphatic. Results suggest that NPMCs improving the quality of information exchange are likely to enhance SM cooperation considerably more than might be the case for PMCs. The more than $20 \%$ difference in explained variance is attributable to the effect of IT (e.g. CRM), as a component of information exchange in PMCs $(r=0.101)$ and NPMCs $(r=0.678)$. PMCs are subject to various GXP regulations (Wingate, 2016) which are not applicable to NPMCs. Validation protocols, including the validation of CRM systems, for example, are extremely strict in PMCs (Wingate, 2016; Elser \&
Richmond, 2019). Based on this, our results are counter-intuitive and need further investigation.

2. How does coordination (common meetings, training sessions, goals, and clearly defined responsibilities) between sales and marketing affect SM cooperation in PMCs and NPMCs?

The marked difference in the coordination variance explained in the management culture (PMC, R2\%=44; NPMC, R2\%=25) might be the result of the strict protocols in PMCs mentioned above. It seems that in PMCs the improvement of coordination is more likely to result in improved SM cooperation than in NPMCs. While clearly defined roles and responsibilities are equally important elements of good coordination in both types of companies, in PMCs it is common meetings whereas in NPMC it is common goals that have the strongest correlation with coordination. Marking clearly defined roles and responsibilities as a high priority to effective coordination runs counter to the practice of B2B companies, where SM responsibilities are largely overlapping, amorphous, and emergent (Biemans \& Makovec Brenčič, 2007; Biemans et al., 2010).

3. How does the company vision and its communication affect SM cooperation in PMCs and NPMCs?

Corporate vision and its communication have a very moderate effect on management culture and through this on SM cooperation in both PMCs $\left(R^{2} \%=16\right)$ and NPMCs $\left(R^{2} \%=18\right)$. What holds true on the company level (Madu, 2013; Tomek et al., 2016; Balmer, 2017) does not seem to be too relevant in an interdepartmental context for the SM relationship. Identifying the exact causes of this requires further investigation that is beyond the scope of this study.

4. How does management culture (information exchange, coordination, vision) affect SM cooperation in PMCs and NPMCs?

The "marketing and sales cooperation" factor is significantly affected by the elements of the

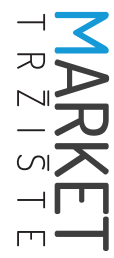




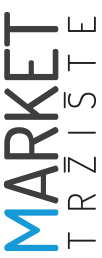

management culture (information exchange, clear corporate vision, coordination). The proportion of variance explained in the two models by management culture, as expressed by the coefficient of determination or $\mathrm{R}^{2}$ is outstanding (PMC, $R^{2}=0,619 ;$ MPMC, $R^{2}=0,741$ ). Our hypothetical belief in the marked combined effect of the three variables seems to have been proved right. This finding draws attention to the importance of examining various factors that affect certain corporate functions not only in isolation, but also in groups where latent mechanisms might create either positive or negative synergies (Birkie, 2016).

5. How do conflicts between sales and marketing affect SM cooperation in PMCs and NPMCs?

Conflicts have no major effect on SM cooperation ( $P C M, R^{2} \%=2 ; N P M C, p=0.298$ ) in either type of companies. Once again, our findings do not seem to support earlier research that emphasized the importance of reducing conflicts to raise corporate competitiveness. The reasons for this might be many, including convenience sampling as a possible cause for the discrepancy between earlier literature and our results. As Henry (2009) pointed out in an empirical study, a large portion of organizational conflicts arise because of interpersonal disagreement and resource scarcity within the company. Based on his results, Henry also emphasized that conflicts can have various positive effects as well. As the case might be, personal disagreement or resource scarcity may not be a significant source of conflicts in the 47 companies surveyed. At the same time, the positive effects of conflicts might counter the negative effects to a higher degree than in other research studies. There might be effective conflict management mechanisms in the examined companies which considerably reduce the potentially negative effects of conflicts while amplifying their positive effects (Longe, 2015; Awan \& Saeed, 2015).

6. How does a shared perception of the ideal customer affect SM cooperation in PMCs and NPMCs?
A shared perception of the ideal customer significantly and almost perfectly equally (PMC, beta=0,568; NPMC, beta=0,584) affects the SM cooperation in PMC and NPMC. While it seems quite obvious that SM departments cannot cooperate efficiently if their perception of what is central to all SM efforts, that is, of the customer, is significantly different, there is no earlier research to rely on in discussing this finding. However, based on our findings and extending on what has been said in the literature review section of the paper, it might be said that, as the examined SM departments use a common CRM platform, they have access to the same customer segmenting and profiling information, greatly helping them to form a shared perception of their customers. As customer-centricity is increasingly important in corporate life in general (Ulaga, 2018) and in the pharmaceutical industry specifically (Panigrahi, Aware \& Patil, 2018), the explanation might lie in PMCs and NPMCs devoting considerable attention to profiling customers and sharing these perceptions within the organization to enhance consistency in delivering value.

As the three variables of the internal models are determined by the 11 input variables of the external model, it can be said that - with the exclusion of conflicts - the SM cooperation is largely determined by information exchange, coordination, vision and communication, and a shared perception of the ideal customer. PLS path modelling is an invaluable SEM technique to uncover latent mechanism in non-normally distributed ordinal level data. This study was exploratory in nature, aiming to highlight the differences and similarities in the way that the selected factors affect SM cooperation in PMCs and NPMCs. Further research might attempt to uncover causes of the differences between PMCs and NPMCs. Findings that run counter to earlier research or seem counterintuitive, such as the insignificant effect of conflicts and the weak effect of corporate vision, are especially intriguing and worth investigating further. Our research has some obvious limitations that restrict the generalizability of its results. For instance, 
convenience sampling with a small number of PMCs nd NPMCs was used; the questionnaire did not include any questions to rule out various responses bias effects; in order to keep the response rate high, a very short questionnaire was employed. In spite of these limitations, our study comparing the SM interface of various types of companies, as a seriously under-researched area at the moment, can yield results of not only theoretical but practical significance as well. As the study was exploratory with a limited number of participants, managerial implications at this point cannot be outlined with any degree of confidence.

\section{References}

1. Ab Hamid, M. R., Sami, W., \& Sidek, M. M. (2017). Discriminant validity assessment: Use of Fornell \& Larcker criterion versus HTMT criterion. Journal of Physics: Conference Series, 890(1), 1-5.

2. Abu Farha, A., \& Elbanna, S. (2018). Do different marketing practices pre-suppose different frames of reference? An exploratory study. Journal of Business \& Industrial Marketing, 33(3), 337352.

3. Ahsan, A. K. (2018). Factors affecting inter-organisational coordination: a case of policy implementation in rural Bangladesh. Development in Practice, 28(8), 1083-1093.

4. Al-jawazneh, B. E. (2015). Conflict handling Styles and Employees' Commitment at the Pharmaceutical Companies in Jordan. International Journal of Business and Management, 10(3), 141-151.

5. Anshari, M., Almunawar, M. N., Lim, S. A., \& Al-Mudimigh, A. (2018). Customer relationship management and big data enabled: personalization \& customization of services. Applied Computing and Informatics, 15, 94-101.

6. Antalóczy, K., \& Sass, M. (2018). The internationalisation of Richter Gedeon, the Hungarian pharmaceutical company, and entrepreneurship in Hungary. In: T. Mets, A. Sauka, \& D. Purg (Eds.), Entrepreneurship in Central and Eastern Europe (pp. 159-176). London: Routledge.

7. Awan, A. G., \& Saeed, S. (2015). Conflict Management and Organizational Performance: A Case Study of Askari Bank Ltd. Research Journal of Finance and Accounting, 6(11), 88-102.

8. Azizi, S., Ghytasivand, F., \& Fakharmanesh, S. (2012). Impact of brand orientation, internal marketing and job satisfaction on the internal brand equity: the case of Iranian's food and pharmaceutical companies. International Review of Management and Marketing, 2(2), 122-129.

9. Balmer, J. M. (2017). Corporate brand orientation: What is it? What of it? In: J. M. T. Balmer, S. M. Powell, J. Kernstock \& T. O. Brexendorf (Eds.), Advances in Corporate Branding (pp. 175-202). London: Palgrave Macmillan.

10. Bauer, R. (2000). Vertriebsorganisation. In: R. Reichwald \& H. J. Bullinger (Eds.), Vertriebsmanagement: Organisation - Technologieeinsatz - Personal (pp. 35-83). Stuttgart: Schäffer-Poeschl.

11. Baum, J. R., Locke, E. A., \& Kirkpatrick, S. A. (1998). A longitudinal study of the relation of vision and vision communication to venture growth in entrepreneurial firms. Journal of applied psychology, 83(1), 43-54.

12. Beverland, M., Steel, M., \& Dapiran, G. P. (2006). Cultural Frames that Drive Sales and Marketing Apart: an exploratory Study. Journal of Business and Industrial Marketing, 21(6), 386-394.

13. Biemans, W. G., \& Makovec Brenčič, M. (2007). Designing the marketing-sales interface in B2B firms. European Journal of Marketing, 41(3/4), 257-273.

14. Biemans, W. G., Brenčič, M. M., \& Malshe, A. (2010). Marketing-sales interface configurations in B2B firms. Industrial Marketing Management, 39(2), 183-194.

15. Bigdeli, A. Z., Kamal, M. M., \& de Cesare, S. (2012). Information sharing in inter-departmental collaboration: a conceptual framework for local government authorities. In: J. R. Gil-Garcia, N. Helbig \& A. Ojo (Eds.), ICEGOV (pp. 485-486). Albany, NY: Palgrawe. 
16. Birkie, S. E. (2016). Operational resilience and lean: in search of synergies and trade-offs. Journal of Manufacturing Technology Management, 27(2), 185-207.

17. Birkinshaw, J., Zimmermann, A., \& Raisch, S. (2016). How do firms adapt to discontinuous change? Bridging the dynamic capabilities and ambidexterity perspectives. California Management Review, 58(4), 36-58.

18. Boe, B. J., Hamrick, J. M., \& Aarant, M. L. (2001). U.S. Patent No. 6,236,975. Washington, DC: U.S. Patent and Trademark Office.

19. Bruhn, M., \& Homburg, C. (2004). Gabler Lexikon Marketing. Wiesbaden: Gabler.

20. Buncher, C. R., \& Tsay, J. Y. (2019). Statistics in the pharmaceutical industry. London: CRC Press.

21. Cespedes, F. V. (1993). Coordinating Sales and Marketing in Consumer Goods Firms. Journal of Consumer Marketing, 10(2), 37-55.

22. Cespedes, F. V. (1994). Industrial Marketing: Managing New Requirements. Sloan Management Review, 35(3), 45-60.

23. Chin, W. W. (1998). The partial least squares approach to structural equation modelling. In: G. A. Marcoulides (Ed.), Modern Methods for Business Research, (pp. 295-333). Mahwah/London: Lawrence Erlbaum.

24. Cohen, J. (1988). Statistical Power Analysis for the Behavioral Sciences. Hillsdale, NJ: Lawrence Erlbaum.

25. Dalla Pozza, I., Goetz, O., \& Sahut, J. M. (2018). Implementation effects in the relationship between CRM and its performance. Journal of Business Research, 89, 391-403.

26. Dewsnap, B., \& Jobber, D. (2000). The Sales-Marketing Interface in Consumer Packaged-Good Companies - Conceptual Framework. Journal of Personal Selling and Sales Management, 20(2) 109-119.

27. Dewsnap, B., \& Jobber, D. (2002). A social psychological model of relations between marketing and sales. European Journal of Marketing, 36(7/8), 874-894.

28. Egelhoff, W. G., \& Wolf, J. (2017). Understanding Matrix Structures and their Alternatives. London: Palgrave Macmillan.

29. Elser, C., \& Richmond, F. J. (2019). Validation Master Plans: Progress of Implementation in the Pharmaceutical Industry. Therapeutic innovation \& regulatory science, 53(3), 354-363.

30. Ernst, H., Hoyer, W. D., \& Rübsaamen, C. (2010). Sales, marketing, and research-and-development cooperation across new product development stages: implications for success. Journal of Marketing, 74(5), 80-92.

31. Erturk, E., \& He, S. (2018). Study on A High-integrated Cloud-Based Customer Relationship Management System. arXiv preprint arXiv:1812.09005.

32. Ferdous, A. S. (2008). Integrated internal marketing communication (IIMC). The Marketing Review, 8(3), 223-235.

33. Fornell, C., \& Larcker, D. F. (1981). Evaluating structural equation models with unob-servable variables and measurement error. Journal of Marketing Research, 18(1), 39-50.

34. Fuller, C. M., Simmering, M. J., Atinc, G., Atinc, Y., \& Babin, B. J. (2016). Common methods variance detection in business research. Journal of Business Research, 69(8), 3192-3198.

35. Garattini, L., \& Padula, A. (2018). Competition in pharmaceuticals: more product-than price-oriented?. The European Journal of Health Economics, 19(1), 1-4.

36. Ghuman, M. K., \& Mann, B. J. S. (2018). Profiling Customers Based on Their Social Risk Perception: A Cluster Analysis Approach. Metamorphosis, 17(1), 41-52.

37. Guenzi, P., \& Troilo, G. (2006). Developing marketing capabilities for customer value creation through Marketing-Sales integration. Industrial marketing management, 35(8), 974-988.

38. Guenzi, P., \& Troilo, G. (2007). The joint contribution of marketing and sales to the creation of superior customer value. Journal of Business Research, 60(2), 98-107. 
39. Guido, G., Pichierri, M., Pino, G., \& Conoci, R. (2018). The Segmentation of Elderly Consumers: A Literature Review. Journal of Customer Behaviour, 17(4), 257-278.

40. Haase, K. (2006), Koordination von Marketing und Vertrieb. Wiesbaden: Deutscher Universitäts-Verlag.

41. Hair, J. F., Ringle, C. M., \& Sarstedt, M. (2011). PLS-SEM: Indeed a silver bullet. Journal of Marketing theory and Practice, 19(2), 139-152.

42. Henry, O. (2009). Organizational Conflict and its effects on Organizational Performance. Research Journal of Business Management, 2(1), 16-24.

43. Henseler, J. (2018). Partial least squares path modeling: Quo vadis?. Quality \& Quantity, 52(1), 1-8.

44. Holden, P. (2018). Marketing Communications in the Pharmaceutical Industry (1 ${ }^{\text {st }}$ ed.). London: CRC Press.

45. Homburg, C., \& Jensen. O. (2007). The Tought Words of Marketing and Sales - Which Differences Make a Difference?. Journal of Marketing, 71(3), 124-142.

46. Homburg C., Jensen O., \& Krohmer H. (2008). Configurations of Marketing and Sales: A Taxonomy. Journal of Marketing, 72(2), 133-154.

47. Homburg, C., Vomberg, A., Enke, M., \& Grimm, P. H. (2015). The loss of the marketing department's influence: is it really happening? And why worry?. Journal of the Academy of Marketing Science, 43(1), 1-13.

48. Homburg, C., Alavi, S., Rajab, T., \& Wieseke, J. (2017). The contingent roles of R\&D-sales versus R\&D-marketing cooperation in new-product development of business-to-business firms. International Journal of Research in Marketing, 34(1), 212-230.

49. Huang, J. C., Wu, T. J., Wen, H. M., Hsin-Fei, W., \& Hairui, J. (2017). Research into the influence of internal interdepartmental integration on service innovation and customer loyalty. In AIP Conference Proceedings (1836(1), 020006). AIP Publishing.

50. Hult, G. T. M., Ketchen, D. J. Jr., \& Slater, S. F. (2002). A Longitudinal Study of the Learning Climate and Cycle Time in Supply Chains. Journal of Business and Industrial Marketing, 17(4), 302-323.

51. Inotai, A., Csanádi, M., Harsányi, A., \& Németh, B. (2017). Drug policy in Hungary. Value in health regional issues, 13, 16-22.

52. Järvinen, J., \& Taiminen, H. (2016). Harnessing marketing automation for B2B content marketing. Industrial Marketing Management, 54, 164-175.

53. Jo Hatch, M., \& Schultz, M. (2003). Bringing the corporation into corporate branding. European Journal of marketing, 37(7/8), 1041-1064.

54. Johnson, J. S., Matthes, J. M., \& Friend, S. B. (in press). Interfacing and customer-facing: Sales and marketing selling centers. Industrial Marketing Management. http://dx.doi.org/10.1016/j.indmarman.2017.08.011

55. Kahn, K. B. (1996). Interdepartmental integration: a definition with implications for product development performance. Journal of product innovation management, 13(2), 137-151.

56. Katsanis, L. P. (2015). Global issues in pharmaceutical marketing. New York, NY: Routledge.

57. Keszey, T., \& Biemans, W. (2016). Sales-marketing encroachment effects on innovation. Journal of Business Research, 69(9), 3698-3706.

58. Kohan, N., Rafie, M., \& Hosseini, S. H. (2014). Assessing the Effect of Intellectual Capital on New Product Development (Case Study: Pharmaceutical Industry of Isfahan Province). International Business and Management, 8(2), 206-213.

59. Kotler, P., Rackham, N., \& Krishnaswamy, S. (2006). Ending the war between sales and marketing. Harvard business review, 84(7/8), 68.

60. Krafft, M. (1995). Aussendienstentlohnung im Licht der Neuen Institutionenlehre. Wiesbaden: Gabler. 
61. Krush, M. T., Malshe, A., Al-Khatib, J., Al-Jomaih, K., \& Katoua, H. (2015). Value Creation within the Sales-Marketing Interface: The Varied Approaches to Integration. Journal of Selling, 14(2), 6-19.

62. Kumazawa, R. (2017). Patenting in the Pharmaceutical Industry. In: S. L. Prabu \& T. N. K. Suriyaprakasha (Eds.), Intellectual Property Rights, IntechOpen. DOI: 10.5772/68102

63. Lamasheva, Y. (2004). International Cooperation and Competitiveness on a Regional Level: Theoretical overview. Social Culture Research, 3(29), 73-94.

64. Le Meunier-FitzHugh, K., \& Piercy, N. F. (2007a). Exploring collaboration between sales and marketing. European Journal of Marketing, 41(7/8), 939-955.

65. Le Meunier-FitzHugh, K., \& Piercy, N. (2007b). Does Collaboration Between Sales and Marketing Affect Business Perforamance?. Journal of Personal Selling and Sales Management, 27(3), 201-220.

66. Le Meunier-FitzHugh, K., \& Lane, N. (2013). Collaboration between sales and marketing, market orientation and business performance in business-to-business organisations. In: N. Lane (Ed.), Strategic Sales and Strategic Marketing (pp. 109-124). London: Routledge.

67. Le Meunier-FitzHugh, K., \& Le Meunier-FitzHugh, L. C. (2016). Sales and Marketing, and Customer Relationships: A Structured Abstract. In: L. Petruzzellis, \& R. S. Winer (Eds.), Rediscovering the Essentiality of Marketing (pp. 779-780). Cham: Springer.

68. Lidstone, J., \& MacLennan, J. (2017). Marketing planning for the pharmaceutical industry ( $2^{\text {nd }}$ ed.). London: Routledge.

69. Longe, O. (2015). Impact of workplace conflict management on organizational performance: A case of Nigerian manufacturing firm. Journal of Management and Strategy, 6(2), 83-92.

70. Madhani, P. M. (2015). Sales and marketing: integration. SCMS Journal of Indian Management, 12(2), 17-28.

71. Madhani, P. M. (2016). Sales and marketing integration: Enhancing competitive advantages. The IUP Journal of Business Strategy, 13(4), 50-77.

72. Madu, B. C. (2013). Vision: The relationship between a firm's strategy and business model. Journal of behavioral studies in business, 6, 1-9.

73. Malshe, A., Friend, S. B., Al-Khatib, J., Al-Habib, M. I., \& Al-Torkistani, H. M. (2017b). Strategic and operational alignment of sales-marketing interfaces: Dual paths within an SME configuration. Industrial Marketing Management, 66, 145-158.

74. Malshe, A., Johnson, J. S., \& Viio, P. (2017a). Understanding the sales-marketing interface dysfunction experience in business-to-business firms: A matter of perspective. Industrial Marketing Management, 63, 145-157.

75. Martinez, L. A. M., \& Hurtado, S. R. F. (2018). Internal Communication Issues in the Firms: Does It Affect the Productivity. Review of European Studies, 10(2), 1-13.

76. Massey, G. R., \& Dawes, P. L. (2007). Personal characteristics, trust, conflict, and effectiveness in marketing/sales working relationships. European Journal of Marketing, 41(9/10), 1117-1145.

77. Matsuo, M. (2006). Customer orientation, conflict, and innovativeness in Japanese sales departments. Journal of Business Research, 59(2), 242-250.

78. Matthyssens, P., \& Johnston, W. J. (2006). Marketing and sales: optimization of a neglected relationship. Journal of Business \& Industrial Marketing, 21(6), 338-345.

79. Mayer, J., \& Nyhuis, P. (2016). Cybernetic Approach for Interdepartmental Cause-effect Relationship Modelling. Universal Journal of Management, 4(9), 488-499

80. Moncrief, W. C. (2017). Are sales as we know it dying... or merely transforming?. Journal of Personal Selling \& Sales Management, 37(4), 271-279.

81. Morgan, N. A., \& Piercy, N. F. (1998). Interactions between Marketing and Quality at the SBU Level: Influences and Outcomes. Journal of the Academy of Marketing Science, 26(3), 190-208. 
82. Morgan, N. A., \& Slotegraaf, R. J. (2012). Marketing capabilities for B2B Firms. In: Lilien, G. L. \& R. Grewal (Eds.), Handbook of Business-to-Business Marketing (pp. 90-108). London: Edward Elgar.

83. Nagy, B. (2018). A gyógyszeripar fejlődése az Európai Unió különböző országcsoportjaiban. In: I. Lengyel (Ed.), Térségek növekedése és fejlődése (pp. 36-51). Szeged: JATEPress.

84. O'Cass, A., Ngo, L. V., \& Siahtiri, V. (2015). Marketing resource-capability complementarity and firm performance in B2B firms. Journal of Business \& Industrial Marketing, 30(2), 194-207.

85. Organisation for Economic Co-operation and Development - OECD (2017). Health at a Glance 2017. OECD Indicators. Paris: OECD.

86. Omar, R., Ramayah, T., Lo, M. C., Sang, T. Y., \& Siron, R. (2010). Information sharing, information quality and usage of information technology (IT) tools in Malaysian organizations. African Journal of Business Management, 4(12), 2486-2499.

87. Paglialonga, A., Patel, A. A., Pinto, E., Mugambi, D., \& Keshavjee, K. (2019). The Healthcare System Perspective in mHealth. In: A. Giuseppe, P. Perego, \& E. Frumento (Eds.), m_Health Current and Future Applications (pp. 127-142). Cham: Springer.

88. Panigrahi, A., Aware, K., \& Patil, A. (2018). Application of integrated marketing communication in pharmaceutical industry. Journal of Management Research and Analysis, 5(2), 133-139.

89. Pepels, W. (2012). Handbuch des Marketing. München: Oldenbourg.

90. Pohludka, M., \& Štverková, H. (2019). The Best Practice of CRM Implementation for Small-and Medium-Sized Enterprises. Administrative Sciences, 9(1), 22-39.

91. Quirke, B. (2017). Making the connections: using internal communication to turn strategy into action. New York, NY: Routledge.

92. Raab, W. (2010). A nemzetközi gazdasági együttműködés lehetőségei és korlátai a két világháború között. In: V. Rab \& Á. Deák (Eds.), Együttmüködés és versengés (pp. 155-161). Budapest: Gondolat Kiadó.

93. Rahim, M. A. (2017). Managing conflict in organizations (4 $4^{\text {th }}$ ed.). New York, NY: Routledge.

94. Rigdon, E. E. (2016). Choosing PLS path modeling as analytical method in European management research: A realist perspective. European Management Journal, 34(6), 598-605.

95. Rouziès, D., Anderson, E., Kohli, A. K., Michaels, R. E., Weitz, B. A., \& Zoltners. A. A. (2005). Sales and marketing integration - A proposed framework. Journal of Personal Selling and Sales Management, 25(2), 113-122.

96. Samart, K., Jansakul, N., \& Chongcheawchamnan, M. (2018). Exact bootstrap confidence intervals for regression coefficients in small samples. Communications in Statistics-Simulation and Computation, 47(10), 2953-2959.

97. Schweitzer, S. O., \& Lu, Z. J. (2018). Pharmaceutical Economics and Policy: Perspectives, Promises, and Problems. Oxford: University Press.

98. Sleep, S., Lam, S. K., \& Hulland, J. (2018). The sales-marketing integration gap: a social identity approach. Journal of Personal Selling \& Sales Management, 38(4), 371-390.

99. Snyder, K., McKelvey, S., \& Sutton, W. (2016). All together now? Exploring sales and marketing integration. Sport, Business and Management: An International Journal, 6(1), 2-18.

100. Song, M. X., Xie, J. \& Dryer, B. (2000). Antecedents and Consequences of Marketing Managers' Conflict-Handling Behaviors. Journal of Marketing, 64(1), 50-66.

101. Specht, G. (1995). Schnittstellenmanagement. In: B. Tietz (Ed.), Handwörterbuch des Marketing (pp. 2265-2275). Stuttgart: Poeschel.

102. Specht, G. (2000). Schnittstellemanagement: Marketing und Forschung \& Entwicklung. In: F. Huber (Ed.), Kundenorientierte Produktgestaltung (pp. 265-286). München: Vahlen.

103. Strahle, W. M., Spiro, R. L., \& Acito, F. (1996). Marketing and sales: strategic alignment and functional implementation. Journal of Personal Selling \& Sales Management, 16(1), 1-20. 
104. Swaim, J. A., Maloni, M., Bower, P., \& Mello, J. (2016). Antecedents to effective sales and operations planning. Industrial Management \& Data Systems, 116(6), 1279-1294.

105. Tenenhaus, M., Vinzi, V. E., Chatelin, Y. M., \& Lauro, C. (2005). PLS path modeling. Computational statistics \& data analysis, 48(1), 159-205.

106. Thornton, G. S. (2019). Strategic Employee Communication. Cham: Palgrave Macmillan.

107. Tomek, G., Vávrová, V., Červenka, P., Naščáková, J., \& Tomčíková, M. (2016). Corporate vision from management development in the globalization context. In: M. Majerník, N. Daneshjo \& M. Bosák (Eds.), Production Management and Engineering Sciences (pp. 297-303). London: Routledge.

108. Ulaga, W. (2018). The journey towards customer centricity and service growth in B2B: a commentary and research directions. AMS Review, 8(1/2), 80-83.

109. Walters, M., \& Bekker, J. (2017). Customer super-profiling demonstrator to enable efficient targeting in marketing campaigns. South African Journal of Industrial Engineering, 28(3), 113-127.

110. Wang, X. H., Fang, Y., Qureshi, I., \& Janssen, O. (2015). Understanding employee innovative behavior: Integrating the social network and leader-member exchange perspectives. Journal of organizational behavior, 36(3), 403-420.

111. Wetzels, M., Odekerken-Schröder, G., \& Van Oppen, C. (2009). Using PLS Path Modeling for Assessing Hierarchical Construct Models: Guidelines and Empirical Illustration. MIS Quarterly, 33(1), 177-195.

112. Wierum, D. (2001). Zusammenarbeit zwischen Personal - und F\&E Bereich - Analyse und Gestaltungsmöglichkeiten auf der Basis des Schnittstellenmanagements. Wiesbaden: Gabler.

113. Wingate, G. (2016). Computer systems validation: quality assurance, risk management, and regulatory compliance for pharmaceutical and healthcare companies. Boca Raton: CRC Press.

114. Wold, H. (1975). Soft Modelling by latent variables: The Non-Linear Iterative Partial Least Squares (NIPALS) approach. In: J. Gani (Ed.), Perspectives in probability and statistics: Papers in honour of M.S. Bartlett on the occasion of his sixty-fifth birthday (pp. 117-142). London: Applied Probability Trust.

115. Wong, K. K. K. (2013). Partial least squares structural equation modeling (PLS-SEM) techniques using SmartPLS. Marketing Bulletin, 24(1), 1-32.

116. Xu, M., \& Walton, J. (2005). Gaining customer knowledge through analytical CRM. Industrial management \& data systems, 105(7), 955-971. 


\section{APPENDIX}

\section{Research questionnaire}

My name is Gabor Hetenyi, head of the present research involving two co-researchers: Dr. Magdolna Szilasi and Dr. Attila Lengyel. Currently, I am working on my PhD dissertation. This survey supports my research and I would kindly ask you to fill it out. The survey is totally anonymous and no personal data, except for demographics, is collected. All data is handled confidentially, third parties excluded. The aggregate results will be published in scientific articles.

\section{All questions are mandatory.}

Your gender:

Your age:

\section{Which area do you work for?}

Marketing Sales General Management

2. Please assess the following statements concerning your company! ( 1 - not at all; 5 - yes completely)

1. The company management has a clear vision for the future.

2. The management communicates the company vision efficiently.

3. The communication between sales and marketing in general is very good.

4. Information exchange between SM departments is optimal.

5. The inter-divisional IT platform (CRM system) greatly helps information exchange.

6. SM staff members have regular common training sessions.

7. SM departments share a common goal they both work for.

8. There are regular common meetings for SM staff members.

9. Sales and marketing have clearly defined areas of responsibilities.

10. Sales and marketing share a mutual perception of the ideal customer.

11. Conflict negatively affect SM cooperation.

3. Would you change ways of cooperation between the two departments in your company? If yes, how? If not, why not? Who would be in charge of changing it?

\section{Which improvements between marketing and sales would you desire?}

shared IT platform, mutual meetings, collective targeting system, regular exchange of information, more acceptance, other: 
